\title{
TUNTUTAN PAMPASAN BAGI KES KEMALANGAN JALAN RAYA DI MALAYSIA: KAEDAH ALTERNATIF BERASASKAN DIYAT
}

\section{Claim of Damages for Road Traffic Accident Cases: The Alternative of Diyat}

\author{
Siti Aisyah Samudin \\ PhD Candidate, Department of Shariah and Law, \\ Academy of Islamic Studies, \\ University of Malaya, 50603 Kuala Lumpur. \\ aisy_awani@um.edu.my \\ Siti Zubaidah Ismail \\ Associate Professor, Department of Shariah and Law, \\ Academy of Islamic Studies, \\ University of Malaya, 50603 Kuala Lumpur. \\ szubaida@um.edu.my
}

\begin{abstract}
The risk of any possible damages in road accident cases may include injuries, death and property damages. Islamic law provides diyat as a compensation mechanism that could only covers bodily injuries and death caused by that accident. On the other hand, any risk of damages involving properties, the compensation in the form of daman will be imposed. It contradicts to the compensation system for injuries and deaths in Malaysia. The Civil Law Act 1956 (CLA 1956) provides compensation for general damages. In this case, the elements of indemnity, which are difficult to quantify and not conclusive appears, such as damages for future earnings loss. Therefore, the objective of this paper is to examine the compensation rate as provided in the diyat by comparing it with the CLA 1956 and the economic status today. Using the collected data analysed from the semi-structured interview and bibliography studies, the research findings indicate that compensation based on diyat according to the gold valuation
\end{abstract}


is the best method and could possibly maximize the justice for road accident victims as the value is more stable compared to the other medium.

Keywords: diyat, compensation, damages, gold valuation, insurance

\section{PENDAHULUAN}

Tuntutan ganti rugi bagi kes kemalangan jalan raya akan berjaya sekiranya pihak penuntut telah memenuhi elemen-elemen ganti rugi sebagaimana yang ditetapkan oleh undang-undang. Dalam hal ini sistem pemberian pampasan sivil sedikit berbeza dengan sistem pemberian pampasan di bawah perundangn syariah yang dikenali sebagai diyat. Perbezaan ini terletak pada elemen ganti rugi yang perlu dipenuhi oleh pihak-pihak yang bertikai.

Bagi undang-undang sivil terdapat dua klasifikasi ganti rugi iaitu ganti rugi khas dan am. Ganti rugi khas ialah ganti rugi yang dapat dikira dengan nilaian ringgit dan sen pada tarikh perbicaraan. Hal ini merangkumi kos bagi rawatan bil-bil hospital, kerosakan pada harta dan sebagainya yang boleh dibuktikan dengan dokumen pada tarikh perbicaraan dilakukan (S. Santhana Dass, 2000: 8). Sebaliknya, ganti rugi am pula adalah ganti rugi yang berbentuk bukan kewangan seperti kesakitan dan penderitaan, kehilangan upaya, pengurangan jangka hayat hidup, kerugian dari sudut prospek perjodohan dan kehilangan konsortium. Ganti rugi am lebih bersifat jangkaan sekiranya kerugian berlaku (Salleh Buang, 1999: 328). Kerugian yang dialami belum muktamad, iaitu dalam keadaan tidak pasti sama ada kerugian tersebut akan berlaku atau tidak. Kadarnya juga tidak dapat diukur dengan rigid, namun pampasan bagi kerugiannya sudah boleh dituntut.

Berbeza dengan diyat, sistem pampasannya tidak mengiktiraf kerugiankerugian yang bersifat jangkaan dan abstrak. Diyat memfokuskan pemberian pampasan atas kerugian yang disebabkan oleh kematian dan kecederaan anggota sahaja dengan pemberian nilai pampasan yang tinggi. Sebaliknya, sebarang risiko kerosakan melibatkan harta benda, ganti rugi berbentuk daman akan dikenakan. Diyat juga boleh diklasifikasikan kepada dua bentuk; diyat sebagai hukuman gantian, iaitu dalam hal hukuman qișās yang diberi kemaafan, ataupun diyat sebagai hukuman asal iaitu dalam situasi perbuatan salah yang tercuai (Paizah Ismail, 2012: 2).

Lantaran itu, kertas penyelidikan ini mendalami konsep diyat dalam aspek hukuman asal iaitu dalam situasi kecuaian yang menjadi penyebab kemalangan jalan raya (tasabbub) (Siti Zubaidah Ismail, 1999: 97). Oleh sebab sistem diyat syariah yang bersumberkan wahyu ini mempunyai asas rujukan serta kadar 
pampasan yang jelas, maka adalah perlu satu kajian khusus dilaksanakan bagi mencari titik integrasi antara diyat dan sistem insurans yang menjadi mekanisme pembayaran pampasan di Malaysia.

\section{SEJARAH KEMUNCULAN DIYAT}

Pendalilan diyat secara jelas dinyatakan menerusi surah al-Nisā’ ayat 92 yang bermaksud:

"Tidak harus sama sekali bagi seseorang Mukmin membunuh seorang Mukmin yang lain, kecuali dengan tidak sengaja. Dan sesiapa yang membunuh seorang Mukmin dengan tidak sengaja, maka (wajiblah ia membayar kaffarah) dengan memerdekakan seorang hamba yang beriman serta membayar "diyah" (denda ganti nyawa) yang diserahkan kepada ahlinya (keluarga si mati), kecuali jika mereka sedekahkan (memaafkannya).

(Surah al-Nisā', 4: 92)

Dalil daripada hadis juga ada diriwayatkan oleh Abu Bakr bin 'Ubayd Allah bin 'Umar, dari 'Umar RA dari Rasulullah SAW bersabda yang bermaksud:

"Pada hidung apabila patah seluruhnya dikenakan diyat 100 unta, pada satu tangan 50 ekor, satu kaki 50 ekor, satu mata 50 ekor, luka yang mengenai kulit otak sepertiga (diyat) pembunuhan, luka yang sampai rongga kepala atau perut sepertiga (diyat) pembunuhan, luka yang sehingga terlihat tulang lima ekor, dan pada setiap jari diyatnya 10 ekor..." 1

Berdasarkan tafsiran daripada nas al-Quran dan matan hadis ini, fuqaha' telah mendefinisikan diyat kepada pelbagai takrif yang membawa kepada skop definisi yang sama iaitu pampasan atas kehilangan. Imam Shāfi'ī mentakrifkan diyat sebagai harta yang merupakan gantian kepada nyawa (al-Shāfi' $\overline{1}, 2001$ : 257). Imam al-Shawkān̄ pula mentakrifkan diyat sebagai satu bayaran yang dikenakan ke atas pelaku salah atau warisnya atas sebab kecuaiannya sehingga menyebabkan kecederaan kepada pihak yang tidak bersalah (alShawkānī, 2004: 1371). Ulama' kontemporari seperti 'Abd al-Qādir 'Awdah mendefiniskan diyat sebagai hukuman gantian kepada qișās, sekiranya ia mengambil tempat kepada hukuman qiṣaș. Ia juga merupakan hukuman asal

Abī Dāwud, Sulayman Ibn al-Ash'ath, Sunan Abī Dāwud, vol. 3 (Bayrūt: Dār alKutub al-'Ilmiyyah, 1996), 193, "Kitāb al-Diyāt, Bāb Diyyāt al-A ‘dha'," no. hadis 4564. 
sekiranya melibatkan jenayah serupa sengaja atau tersalah (Paizah Ismail, 2012: 2).

Sejarah kemunculan diyat dan pelaksanaannya wujud dalam kalangan bangsa Arab Jahiliyyah. Pada awalnya diyat merupakan satu bentuk bayaran pampasan atas kelakuan jenyah yang dilakukan oleh ahli kabilah para Arab Jahiliyyah. Oleh sebab itu, tidak salah jika dinyatakan bahawa diyat adalah satu bentuk adat yang diperturunkan melalui satu generasi kepada generasi yang lain melalui pengamalan masyarakatnya. Pelaksanaan hukuman darah dibayar wang merupakan satu bentuk pelaksanaan pampasan yang bersifat universal berikutan ia turut diamalkan oleh hampir semua masyarakat purba termasuk masyarakat Arab Jahiliyyah (Siti Zubaidah Ismail, 2005: 127). Malahan, ia turut menyamai hukuman wergild (man payment) dalam perundangan kuno Roman, Jerman dan Anglo-Saxon (Mohammad Ali Heidari, 2015: 4-6).

Diyat dalam kalangan masyarakat Arab Jahiliyyah pula sangat dekat dengan amalan dendam dan penjagaan maruah antara kabilah. Mereka mengekspresikan perasaan marah dan kesumat mereka melalui tindakan balas dendam. Pihak yang bermusuh akan saling membalas bagi menjaga darah ahli kabilah atas dasar kebersamaan dan semangat kekitaan yang begitu tinggi (Mohd. Shukri Hanafi, 2013: 216). Permusuhan dan balas dendam boleh berlarutan sekiranya terdapat kelakuan jenayah yang dilakukan oleh ahli kabilah kepada kabilah yang lain. Mereka memegang kuat prinsip darah harus dibayar dengan darah biarpun tindakan jenayah itu bukan suatu yang disengajakan (Kirazli, S. B. T.-I. S., 2011: 35-36).

Kaedah diyat pada awalnya masih didasari oleh perasaan dendam yang kuat tanpa mengutamakan keadilan. Penetapan kadar pampasan dibuat mengikut status dan kedudukan ahli kabilah tersebut. Sekiranya kabilah itu kuat dan dipandang tinggi maka kadar pampasannya juga adalah tinggi. Sebaliknya, jika kabilah tersebut lemah, maka kadar pampasan yang akan dibayar juga adalah rendah (Muhammad Suhail Toqush, 2009: 159). Kedatangan Islam menganjurkan diyat sebagai satu sistem yang diperakui syariah melalui rujukan kepada wahyu al-Quran dan hadis.

\section{PENETAPAN NILAI DIYAT BERDASARKAN NAS SYARAK}

Sebelum perbincangan berkenaan kadar diyat disentuh, perkara utama yang perlu diperhalusi ialah berkenaan medium untuk membayar diyat. Adakah berbentuk matawang atau barang-barangan seperti barangan zakat $^{2}$ atau

\footnotetext{
2 Medium zakat adalah seperti makanan ruji sesebuah negara seperti beras, gandum, kurma.
} 
bagaimana? Pada dasarnya, sebagaimana kebanyakan isu yang menjadi khilaf daam permasalahan fiqh, medium pembayaran diyat juga mempunyai khilaf dalam kalangan fuqaha'. Khilaf ini timbul oleh kerana perbezaan waqi' (situasi semasa) dan kefahaman para ulama.

\section{MEDIUM-MEDIUM PEMBAYARAN DIYAT}

Terdapat enam medium pembayaran diyat yang terlibat merangkumi unta, emas, perak, lembu, kambing dan pakaian. Medium-medium ini boleh diklasifikasi kepada tiga pandangan. Pandangan pertama mewajibkan pembayaran diyat menggunakan medium unta atau emas atau perak. Pandangan ini dipelopori oleh kalangan mazhab Imam Abu Hanifah dan Imam Malik bersandarkan kepada hadis riwayat Abu Dawud dalam sahihnya Rasulullah SAW bersabda: bagi jiwa seorang perempuan beriman adalah 100 ekor unta. ${ }^{3}$ Dalil emas dan perak pula tsabit di sisi Imam Abu Hanifah melalui penulisan al-Sarkhasi yang menyatakan peristiwa pada zaman Rasulullah bahawa seorang lelaki yang mencederakan tangan pemuda lain, maka dihukumkan ke atasnya separuh diyat iaitu sebanyak 5,000 dirham. ${ }^{4}$ Nas ini menjadi dalil keharusan membayar diyat menggunakan emas atau perak. Maka, ketiga-tiga medium ini menjadi asas bagi Mazhab Hanafi dan Maliki dalam pembayaran diyat ke atas mangsa yang tercedera (Yasin Ahmad Ibrahim, 1990: 557).

Pendapat kedua hanya membolehkan unta sebagai medium pembayaran diyat. Pendapat ini dipelopori oleh mazhab Shāfi' $\overline{1}$ dan satu riwayat daripada Imam Ahmad yang menyatakan bahawa diyat bagi seorang Muslim merdeka pada asasnya ialah 100 ekor unta sahaja (Yasin Ahmad Ibrahim, 1990: 558). Pendapat ini disokong dengan beberapa dalil hadis dan peristiwa pada zaman Rasulullah SAW antaranya hadis riwayat Abu Bakr bin Muhammad bin Amru bin Hazm daripada ayahnya daripada datuknya bahawasanya Rasulullah SAW menulis kepada ahli Yaman yang terkandung di dalamnya berkenaan faraid, sunah-sunah, dan juga diyat. Tulisan tersebut dibacakan kepda penduduk Yaman bahawasanya bagi setiap jiwa itu 100 ekor unta. Maka, hadis ini menunjukkan bahawa asal bagi pembayaran diyat adalah unta kerana hadis telah menukilkan perkara tersebut.

$3 \quad$ Abī Dāwud, Sulayman Ibn al-Ash'ath, Sunan Abī Dāwud, vol. 3 (Bayrūt: Dār alKutub al-'Ilmiyyah, 1996), 193, "Kitāb al-Diyāt, Bāb Diyyāt al-A'dha'," no. hadis 4564.

$4 \quad$ Abī Dāwud, Sulayman Ibn al-Ash'ath, Sunan Abī Dāwud, vol. 3 (Bayrūt: Dār alKutub al-'Ilmiyyah, 1996), 193, "Kitāb al-Diyāt, Bāb Diyyāt al-A'dha'," no. hadis 4564. 
Hadis lain yang menjadi sandaran adalah melalui sabda Rasulullah SAW bahawa bagi pembunuhan menyerupai sengaja iaitu menggunakan rotan atau tongkat diyatnya adalah 100 ekor unta (Yasin Ahmad Ibrahim, 1990: 558). Melalui hadis ini baginda SAW membezakan antara diyat bagi pembunuhan sengaja dan cuai iaitu dengan menetapkan diyat yang berat bagi sebahagiannya serta diyat yang ringan bagi sebahagian yang lain. Penetapan niat yang berbeza ini walau bagaimanapun tidak langsung dianggar dengan menggunakan selain unta melainkan dengan unta juga (Ibid: 559).

Peristiwa lain yang mendokong pendapat ini sebagaimana yang diriwayatkan oleh Amru bin Shuaib daripada ayahnya daripada datuknya bahawa nilai diyat pada zaman Rasulullah adalah 800 dinar atau 8,000 dirham. Keadaan sedemikian berlaku sehinggalah 'Umar RA dilantik menjadi khalifah. Maka 'Umar RA melantik seorang khatib dan khatib tersebut berkata sesungguhnya harga unta telah meningkat tinggi. Maka 'Umar RA berkata: bagi orang yang memiliki emas 1000 dinar, pemilik kertas 12,000 dirham, pemilik lembu 2,000 ekor lembu, pemilik kambing dua ribu ekor kambing dan pemilik pakaian 200 helai pakaian. Situasi ini menunjukkan bahawa 'Umar tidak memberi nilaian sedemikian kepada siapa yang memiliki unta, sebaliknya kadaran tersebut tertakluk kepada mereka yang tidak memilikinya (Abi Ali Hassan, 1979: 1081)

Imam Shāfi 'ī menegaskan bahawa medium pembayaran diyat pada asasnya dikehendaki dengan menggunakan unta sahaja. Sekiranya situasi pada zaman tersebut menghendaki berpindah kepada nilaian lain seperti emas atau perak, maka nilaian tersebut perlu dinisbahkan dengan nilaian unta sebagaimana yang berlaku pada zaman Rasulullah SAW dan 'Umar RA (Yasin Ahmad Ibrahim, 1990: 562).

Pendapat ketiga pula mewajibkan pembayaran diyat menggunakan salah satu daripada keenam-enam medium iaitu emas, perak, unta, lembu, kambing dan pakaian. Pendapat ini dipelopori oleh Imam Abu Yusuf dan Muhammad dan satu riwayat daripada Imam Ahmad (Abi Ali Hassan, 1979: 1082). Antara hadis yang menjadi sandaran adalah riwayat Atha' bin Jabir di mana Rasulullah SAW memfardhukan diyat ke atas pemilik unta 100 ekor unta, pemilik lembu 200 ekor lembu, pemilik kambing 1,000 ekor kambing dan pemilik pakaian 2,000 helai pakaian (Ibid). Hadis ini mendokong wajibnya pembayaran diyat dengan menggunakan salah satu daripada medium unta, lembu, kambing, atau pakaian. Pembayaran diyat dengan menggunakan emas atau perak pula disokong melalui satu peristiwa yang diriwayatkan oleh Ibn Abbas RA bahawa terdapat seorang lelaki daripada Bani A'di terbunuh, maka Nabi SAW menetapkan diyat baginya sebanyak 12,000 dirham. Begitu juga dengan satu peristiwa yang berlaku pada zaman 'Umar RA apabila beliau menetapkan bagi pemilik emas 1000 dinar melalui riwayat 'Umar Ibn Hazm dan al-Sya'bi. 
Walau bagaimanapun, medium pembayaran diyat ini boleh ditukarkan kepada nilaian matawang kini yang menjadi medium utama transaksi urus niaga di dunia (Muhammad Hilmi Musa, 2015: 24). Hal ini dirujuk dalam situasi zakat yang membolehkan pembayaran zakat mengikut nilaian beras dengan menggunakan matawang ringgit Malaysia kerana pemerintah menghukumkan berfitrah dengan wang itu kerana pihak asnaf atau mangsa kemalangan lebih suka menerima wang daripada beras. Selain itu, menyimpan wang lebih selamat kerana selain daripada menyusahkan pihak pemerintah, pejabat agama akan memerlukan upah untuk mengangkutnya - akan rosak jika disimpan lama. ${ }^{5}$

Lantaran itu, kertas penyelidikan ini mencadangkan penentuan kadar diyat dengan dinisbahkan kepada nilai dinar emas kerana nilai harganya yang lebih stabil dan sentiasa meningkat berbanding nilai medium-medium lain. Peningkatan nilai ini menjadi simbol mahalnya nyawa dan anggota tubuh badan yang tidak akan jatuh nilainya bahkan semakin meningkat. Walaupun begitu, nilaian ini masih boleh diberi pentafsiran semula berdasarkan ijtihad dengan melihat situasi dan status kewangan semasa negara. Sekiranya nilai diyat dinisbahkan kepada emas, maka 1 dinar emas ialah bersamaan dengan 4.25 gram emas 916 (22k) iaitu dengan harga belian RM148.79.00 bagi $1 \mathrm{~g}$ emas. 4.25 gram emas 916 adalah bersamaan RM 632.00. Oleh itu, ukuran nilai diyat penuh ialah 1000 dinar emas yang bersamaan RM632,000 Manakala, 1/2 daripada nilai diyat penuh ialah RM316,000 dan begitulah seterusnya. ${ }^{6}$

\section{KADAR DAN PEMBAHAGIAN DIYAT BAGI KEHILANGAN NYAWA DAN KECEDERAAN ANGGOTA}

Diyat boleh dikategorikan kepada dua jenis mengikut kesalahan iaitu diyat ringan (mukhaffafah) dan diyat berat (mughallazah). Diyat mughallazah merupakan bayaran diyat yang dikenakan ke atas pembunuhan secara sengaja dalam situasi waris memberi kemaafan kepada pelaku. ${ }^{7}$ Diyat mukhaffafah pula dikenakan ke atas pesalah yang melakukan pembunuhan akibat kecuaiannya seperti orang yang cuai sehingga mengakibatkan kecederaan atau kematian.

5 Jawatankuasa Fatwa Kebangsaan (2003), "Muzakarah Jawatankuasa Fatwa Kebangsaan Bagi Hal Ehwal Ugama Islam Malaysia Kali Ke-57," http://www. islam.gov.my/images/ePenerbitan/KOMPILASI_MUZAKARAH_MKI_2016. pdf, dicapai pada 20 November 2017.

6 Harga Emas Trading, "Harga Emas Hari Ini", laman sesawang Harga Emas Trading Sdn Bhd, dicapai pada 10 Januari 2017, http://www.hargaemas.com.my/).

7 Dalam situasi ini, diyat berperanan sebagai hukuman ganti kepada hukuman qiṣāṣ. 
Diyat mukhaffafah merupakan satu diyat penuh iaitu dengan kadar RM632,000 mengikut nisbah nilai emas yang dibayar secara beransur-ansur (tangguh) selama 3 tahun dan setiap tempoh masa satu tahun dibayar 1/3 diyat. Kadar diyat mukhaffafah pada asalnya turut dinilai menggunakan nilaian unta. Hal ini bertepatan dengan hadis Nabi SAW yang bermaksud:

'Diyat khata' diperincikan kepada lima jenis, iaitu 20 ekor unta dengan umur empat tahun, 20 ekor unta dengan umur lima tahun, 20 ekor unta betina dengan umur satu tahun masuk tahun kedua, 20 ekor unta dengan umur dua tahun masuk tahun ke tiga dan 20 ekor unta jantan dengan umur dua tahun, masuk tahun ketiga.. " 8

Walau bagaimanapun, pelaksanaan sistem diyat ini berkembang dengan wujudnya sistem barter dan transaksi kewangan. Sistem nilaian unta sebagai alat pembayaran diyat menjadi keutamaan pada zaman Rasulullah SAW yang kemudiannya dipermudahkan lagi dengan adanya sistem mata wang dinar dan dirham (Muhammad Hilmi Musa, 2015: 22). Pemerintahan Khalifah 'Umar al-Khattab membawa perubahan baru kepada sistem nilaian diyat iaitu dengan menyeragamkan nilai 1 diyat bersamaan 1000 dinar emas atau 12000 dirham perak berdasarkan kepada perubahan ekonomi dan nilai pasaran unta. ${ }^{9}$

Kadar diyat dijelaskan dalam kitab-fiqh fiqh klasik seperti al-Umm dengan melihat kepada beberapa kategori mangsa tersebut iaitu gender sama ada lelaki atau wanita, sifatnya sama ada bebas atau hamba dan juga agamanya, iaitu Islam atau selainnya. Fuqaha' bersepakat bahawa kadar diyat bagi seorang lelaki Muslim merdeka yang kehilangan nyawa secara tersalah atau cuai maka kadarnya ialah satu diyat penuh bersamaan 100 ekor unta. Hal ini adalah berdasarkan hadis riwayat al-Tirmidhi yang bermaksud:

"Barangsiapa membunuh seorang Mukmin yang merdeka, maka perkaranya diserahkan kepada wali korban. Apabila mereka menghendaki, mereka boleh membunuh dan apabila mereka menghendaki, mereka boleh mengambil diyat. Iaitu berupa 30 ekor hiqqah (unta betina berumur tiga tahun masuk empat tahun), 30 ekor jadza'ah (unta betina berumur empat tahun masuk lima tahun) dan 40 ekor khalifah (unta betina yang sedang bunting).

\footnotetext{
$8 \quad$ Abī Dāwud, Sulayman Ibn al-Ash'ath, Sunan Abī Dāwud, vol. 3 (Bayrūt: Dār alKutub al-'Ilmiyyah, 1996), 193, "Kitāb al-Diyāt, Bāb Diyyāt al-A'dha',” no. hadis 4564.

9 Nilai seekor unta pada zaman Rasulullah adalah bersamaan 800 dinar emas atau 8,000 dirham perak.
} 
Apa yang baik bagi mereka, maka mereka boleh mengambilnya.

Yang demikian untuk memberatkan tebusan..."

Imam Shāfi'ī berpandangan sekiranya mangsa adalah hamba, maka diyatnya adalah separuh daripada diyat seorang merdeka. Sekiranya mangsa adalah seorang wanita Muslimah merdeka, maka diyatnya adalah separuh daripada diyat lelaki Muslim yang merdeka, iaitu sebanyak 50 ekor unta. Kewajipan ini merangkumi pembunuhan yang dilakukan oleh pesalah lelaki mahupun wanita (Paizah Ismail, 2012: 12).

\section{KADAR DIYAT BAGI KEHILANGAN DAN KECEDERAAN ANGGOTA}

Kadar diyat bagi anggota yang tercedera, hilang atau tidak berfungsi dinilai melalui bilangan anggota tersebut sama ada tunggal atau berpasangan. Bagi anggota tunggal seperti hidung yang menyebabkan hilang upaya untuk menghidu, atau lidah yang menyebabkan hilang upaya untuk bertutur atau zakar yang menyebabkan hilang keupayaan bersetubuh atau lumpuh seluruh badan, maka kadarnya ialah satu diyat penuh bagi satu anggota tersebut iaitu bersamaan seratus ekor unta. Kadar ini dirujuk melalui hadis Rasulullah SAW yang bermaksud:

“Adapun pada jiwa diyatnya 100 ekor unta, pada hidung apabila patah seluruhnya dikenakan diyat penuh, pada lidah diyat penuh, pada dua mulut diyat penuh, pada dua buah zakar diyat penuh, pada zakar diyat penuh..." 10

'Umar al-Khattab RA dalam tempoh pemerintahannya turut mengenakan diyat penuh bagi anggota yang masih wujud, namun kehilangan fungsinya. Hal ini dirujuk melalui satu peristiwa yang diceritakan oleh 'Auf rahimahullah yang berkata:

"Aku mendengar ada seorang lelaki telah bertingkah aneh, maka orang ramai menyatakan bahawa itu adalah Abu al-Muhallab, Pak Cik dari Abu Qilabah.'Perawi berkata, 'Seseorang melempar kepalanya dengan sebuah batu, lalu hilanglah pendengaran, fungsi lidah, akal, dan fungsi kemaluannya sehingga tidak bisa (berhubungan dengan) wanita. Lalu 'Umar RA memutuskan agar pelaku membayar empat kali diyat”. (al-Kufi: 268920)

10 Abī Dāwud, Sulayman Ibn al-Ash'ath, Sunan Abī Dāwud, vol. 3 (Bayrūt: Dār alKutub al-'Ilmiyyah, 1996), 193, "Kitāb al-Diyāt, Bāb Diyyāt al-A'dha'," no. hadis 4564 . 
Seterusnya, kadar diyat bagi anggota berpasangan seperti mata, tangan, kaki dan selainnya diyatnya adalah sebanyak 50 ekor unta. Sekiranya kecederaan melibatkan kedua-dua anggota berpasangan ini maka diyatnya adalah 100 ekor unta. Hal ini dirujuk bersandarkan hadis riwayat Abu Bakar bin 'Ubayd Allah bin 'Umar, dari 'Umar RA dari Rasulullah SAW bahawa beliau bersabda:

"Pada hidung apabila patah seluruhnya dikenakan diyat 100 unta, pada satu tangan 50 ekor, satu kaki 50 ekor, satu mata 50 ekor..." 11

Selain kehilangan anggota, diyat juga diperuntukkan bagi kecederaan berbentuk luka geseran atau koyakan yang boleh dikenali dengan pelbagai istilah tertentu sebagaimana yang disebut di dalam hadis Rasulullah SAW. Kecederaan jenis ini adalah termasuk dalam diyat syijaj iaitu luka pada kepala atau wajah.

Bagi luka yang sampai ke dalam bahagian otak (al-ma'mūmah), dan luka yang sampai ke selaput kepala, (al-dāmighah), diyatnya adalah 33 ekor unta (1/3 diyat). Bagi luka yang membuat tulang terlihat diyatnya ialah sebanyak lima ekor unta, luka yang meremukkan tulang sebanyak 10 ekor unta, kecederaan yang memindahkan serta mematahkan tulang sehingga tergeser dari tempat asalnya sebanyak 15 ekor unta, kecederaan bagi anggota berpasangan yang memiliki kelopak seperti empat kelopak mata sebanyak 25 ekor unta, kecederaan bagi anggota yang mempunyai sendi atau bahagian seperti jari tangan dan kaki, kadar diyatnya ialah sebanyak 1/10 diyat bagi satu sendi.

Terdapat juga kecederaan lain yang tidak diperuntukkan diyat di dalamnya iaitu luka yang melukai kulit, namun tidak mengeluarkan darah (alkharisah), luka yang mengeluarkan darah (al-dāmiyah), luka yang merobek daging dengan sobekan besar (al-ba'dhiyah), luka yang menembusi daging (al-mutalahimah), dan luka yang hampir menembusi tulang (al-simhāq). Kadar diyat bagi kecederaan anggota ini ditetapkan berdasarkan hadis yang diriwayatkan oleh Abu Bakar bin 'Ubayd Allah bin 'Umar, dari 'Umar RA dari SAW bahawa beliau bersabda yang maksudnya:

"Pada hidung apabila patah seluruhnya dikenakan diyat 100 unta, pada satu tangan 50 ekor, satu kaki 50 ekor, satu mata 50 ekor, luka yang mengenai kulit otak sepertiga (diyat) pembunuhan, luka yang sampai rongga kepala atau perut sepertiga (diyat)

$11 \quad$ Abī Dāwud, Sulayman Ibn al-Ash'ath, Sunan Ab̄̄ Dāwud, vol. 3 (Bayrūt: Dār alKutub al-'Ilmiyyah, 1996), 193, "Kitāb al-Diyāt, Bāb Diyyāt al-A“dha'," no. hadis 4564 . 
pembunuhan, luka yang membuat tulang terlihat lima ekor, dan pada setiap jari diyatnya 10 ekor." (Al-Daruquthni: 357)

Satu peristiwa lain turut menyatakan berkenaan kadar diyat, iaitu melalui Abu Bakar bin Muhammad bin 'Amr bin Hazm daripada ayahnya dan datuknya RA menyatakan perihal Nabi SAW, bahawasanya beliau menulis surat untuk penduduk Yaman, di dalamnya tertulis tentang kewajiban-kewajiban, hal-hal yang sunnah serta pendalilan diyat.

\section{JUSTIFIKASI DIYAT SEBAGAI KAEDAH PEMBERIAN PAMPASAN}

\section{Kesamaan Antara Prinsip Diyat dan Keadilan Restoratif}

Kajian ini mengambil pendekatan diyat sebagai medium penyelesaian luar mahkamah berikutan terkandung di dalamnya satu bentuk keadilan restoratif. ${ }^{12}$ Walaupun diyat seringkali dianggap sebagai wang darah (blood money), namun terma yang paling dekat bagi menggambarkan diyat ialah pampasan atau pengembalian. Hal ini merujuk kepada wang yang dipampas atau dikembalikan kepada mangsa atau waris kerana wujudnya kerugian yang disebabkan oleh pihak lain. Diyat dalam maksud keadilan restoratif lebih mengutamakan kebajikan mangsa berbanding tumpuan hukuman ke atas pesalah sebagaimana yang diamalkan dalam sistem hari ini. Hal ini bermaksud, apabila satu kemalangan berlaku, maka fokus utama yang perlu dicari ialah siapakah pihak mangsa yang terlibat, apakah kerugian yang dialaminya dan bagaimana keadilan boleh diberi kepada mangsa dalam tempoh segera. Keadilan restoratif turut menilai perlakuan jenayah sebagai satu perlakuan berbahaya yang perlu dipulihkan melalui proses holistik yang menghubungkan mangsa, pesalah dan masyarakat secara langsung. Oleh sebab itu, peranan pihak-pihak ini dalam proses penyelesaian pertikaian adalah diiktiraf. Situasi ini dapat dilihat dalam pelaksanaan diyat apabila pihak yang bersalah seringkali diwakili oleh 'aqilah mereka. Walaupun terdapat pelbagai tafsiran 'aqilah yang diberi oleh fuqaha', namun nyatanya 'aqilah adalah penglibatan ahli masyarakat yang menyerupai sistem keadilan restoratif.

12 Keadilan restoratif seringkali dikaitkan dengan undang-undang berbentuk pemulihan iaitu memulihkan kembali kerugian yang dialami pihak-pihak. 


\section{Hukuman Penjara}

Selain terdapatnya prinsip keadilan restoratif dalam sistem diyat, cadangan sistem ini sebagai medium tuntutan pampasan juga tidak memerlukan pesalah untuk masuk ke dalam penjara bagi kesalahan yang murni kerana kecuaian sekali gus mampu menyelesaikan masalah kesesakan di dalam penjara. Dalam hal ini, penulis tidak menafikan hukuman ini seperti yang diamalkan oleh sistem perundangan sekarang sememangnya memberi kesan berat ke atas pesalah yang cuai mengakibatkan kemalangan. Sebagai contoh, seksyen 40 Akta Pengangkutan Jalan 1984 mensabitkan hukuman penjara selama tempoh tidak lebih lima tahun bagi kesalahan memandu secara melulu dan membahayakan. ${ }^{13}$ Walau bagaimanapun, dari sudut lain, kesan itu bukan hanya dirasai oleh pesalah, tetapi juga tanggungan mereka. Sekiranya pesalah ialah ketua keluarga atau orang yang memberi sumbangan dalam keluarga, pemenjaraan mereka sudah tentu memberi impak negatif kepada waris atau tanggungan. Hal ini menyebabkan fokus dan matlamat utama ganti rugi ke atas mangsa sedikit lari apabila ada kelompok lain yang terjejas iaitu pihak yang ditanggung pesalah. Oleh sebab itu, penulis berpandangan sekiranya kemalangan terjadi adalah kerana kecuaian yang tidak disengajakan, maka hukuman penjara ini perlu diteliti semula. ${ }^{14}$

Selain itu, bebanan kerajaan dalam menguruskan kos banduan dan penyelenggaraan penjara mampu juga mampu dikurangkan. Kos penyelenggaraan penjara merangkumi pemasangan televisyen litar tertutup (CCTV), makanan harian bagi banduan yang mencecah RM40.00 seorang untuk sehari, dan sebagainya sudah tentu berkurangan sekiranya kerajaan melaksanakan sistem diyat dalam pemberian pampasan di Malaysia (Wan Roslili Abd. Majid, 2015: 43).

\section{Diyat Bertepatan dengan Human Life Value Factor (HLVF)}

Faktor Nilai Hidup Manusia (HLVF) merupakan kaedah pengiraan saintifik bagi mengukur kadar kewangan sebenar yang diperlukan oleh insurans hayat manusia. Kajian berkenaan kaedah ini dijalankan oleh Haslifah Hashim dan David Service dalam artikel bertajuk Modelling the Life Insurance Needs

13 Seksyen 40 Akta Pengangkutan Jalan 1987 sebagai contoh mensabitkan hukuman penjara selama tempoh tidak lebih lima tahun bagi kesalahan memandu secara melulu dan membahayakan.

14 Sekiranya kemalangan berlaku akibat kecuaian yang disengajakan atau boleh dijangka seperti kemalangan yang berlaku akibat berada di bawah pengaruh alkohol atau dadah, maka penulis menyokong penuh hukuman penjara dilaksanakan. 
Using the Human Life Value Revision Method. Haslifah Hashim dalam kajiannya mendapati bahawa kadar pampasan yang ditetapkan mahkamah atau pihak insurans adalah jauh lebih rendah berbanding kadar yang diperlukan oleh hayat manusia. Hal ini dibuktikan melalui beberapa kes terpilih seperti Mohamed Mat Amin \& ORS v Mohd Rabu Ihsan [2002]5 CLJ. Hakim telah menetapkan pampasan gantirugi sebanyak RM72,000, namun nilai sebenar setelah kaedah saintifik ini digunakan ialah sebanyak RM109,044. Begitu juga dalam kes Azman Kasri \& Anor v Md. Isa Endut \& Government of Malaysia [1988] 1 CLJ, Hakim memutuskan kadar pampasan bagi kehilangan sumber pendapatan pada masa hadapan bagi Plaintif ialah sebanyak RM39,740, namun nilai sebenar setelah kaedah saintifik ini digunakan ialah sebanyak RM284,953 (Haslifah Hashim \& David Service, 2013: 1-10). Meneliti kepada perbezaan kadar pampasan ini, penulis berpandangan kaedah diyat merupakan kaedah paling sesuai untuk dilaksanakan disebabkan penetapan nilai setiap anggota yang tinggi dan lebih mudah untuk dirujuk serta diikuti oleh mahkamah.

\section{Diyat sebahagian daripada Tort}

Diyat merupakan kaedah pemberian pampasan yang diberikan kepada pihak yang mengalami kerugian. Sekiranya dibuat perbandingan dengan undangundang sivil, kita akan mendapati kaedah diyat diletakkan di bawah undangundang tort, bukan undang-undang jenayah. Penulis berpandangan bahawa kaedah diyat yang merupakan sebahagian daripada undang-undang tort tidak akan menjadi isu atau polemik yang sebegitu besar sebagaimana yang berlaku kepada hukuman hudud. Kaedah ini barangkali agak janggal untuk diketengahkan kepada masyarakat pada awalnya, namun akan mudah diterima dan dilaksanakan sebagaimana yang berlaku dalam sistem perbankan Islam di Malaysia. Tambahan pula, kita sudah mempunyai asas dan kerangka model diyat yang prinsipnya menyerupai keadilan restoratif serta lebih dekat dengan masyarakat. Tinggal lagi, kerangka diyat yang didasari al-Quran dan hadis ini perlu dikembangkan sesuai dengan nilai dan maslahat masyarakat hari ini. Mengapa tidak kita guna dan laksanakan?

\section{PENUTUP}

Perbincangan berkenaan tuntutan pampasan ke atas mangsa kemalangan jalan raya merupakan satu usaha berterusan bagi memastikan pihak mangsa mendapat keadilan terbaik. Kertas penyelidikan ini cuba mengetengahkan peranan diyat sebagai alternatif dalam usaha menambah baik sistem pemberian pampasan sedia ada. Pengharmonian antara sistem undang-undang sivil dan syariah yang 
semakin mendapat perhatian mampu membuka ruang kepada pengharmonian diyat dalam sistem pampasan sivil. Peranan diyat sebagai kaedah pampasan dalam masyarakat Islam kontemporari perlu diserlahkan kerana kesusasteraan sedia ada adalah lebih dari mencukupi dalam menunjukkan kepentingannya. Merujuk kepada justifikasi yang diberikan, pelaksanaan diyat sebagai medium tuntutan pampasan bagi kes kemalangan jalan raya mampu menjadi alternatif terbaik untuk diaplikasikan di Malaysia. Sistem diyat yang mengetengahkan kadar pampasan bersifat tetap dan sejajar dengan nilai emas semasa amat penting bagi menyeimbangkan keadilan antara mangsa dan pihak pembayar pampasan. Lantaran itu, kajian seterusnya boleh diteruskan dengan mengemukakan cadangan kuantum ganti rugi sesuai dengan merujuk kepada kuantum ganti rugi yang telah dinilai oleh pihak mahkamah dan diintegrasikan dengan kaedah diyat menurut Islam.

\section{PENGHARGAAN}

Artikel ini merupakan sebahagian dari hasil kajian projek bertajuk "Kemalangan Jalan Raya dan Keadilan terhadap Mangsa: Pelan Tindakan dan Penyelesaian Menurut Prinsip Perundangan Islam" yang ditaja oleh Kementerian Pengajian Tinggi Malaysia menerusi dana Fundamental Research Grants Scheme (FRGS FP022-2015A). Terima kasih kepada Kementerian Pengajian Tinggi dan Universiti Malaya atas kemudahan penyelidikan yang diberikan.

\section{RUJUKAN}

Abī Dāwud, Sulayman Ibn al-Ash‘ath, Sunan Abī Dāwud, vol. 3 (Bayrūt: Dār al-Kutub al-'Ilmiyyah, 1996).

Al-Bahisin, Ya'qūb Ibn 'Abd al-Wahāb (2012). Qa 'idah al- 'Adah Muhakkamah Dirāsah Nazariyyah Ta siliyyah Tatbiqiyyah. Riyād: Maktabah al-Rushd.

Al-Banna, Ab̄̄ 'Alī Hassan Ibn Ahmad (1989). al-Muqni’fi Sharh Mukhtassar al-Khiraqi, vol. 1. Riyād: Maktabah al-Rushd.

Al-Dāruqutni (2011). Sunan al-Daruqutni (Bayrūt: Dār Ibn Hazm).

Al-Kūfi, Ibn Shaybah 'Abd Allāh bin Muhammad (1989). al-Kitāb alMusannaffi al-Ahādith wa al-Athār. Beirūt: Dār al-Tāj.

al-Shāfi'1̄, Muhammad Ibn Idris (2001). al-Umm, Kitāb Diyāt al-Khata'. Mansūrah: Dar al-Wafa' wa al-Tabā'ah li al-Nashr wa al-Tawzī'.

al-Shawkān̄̄, Muḥammad Ibn 'Alī (2004). Nayl al-Awțār Sharḥ Muntaqa alAkhbar. Bayrūt: Bayt al-Afkār al-Dawliyyah. 
Berita Semasa, "Diyat", laman sesawang Majlis Dakwah Negara, http://www. mdn.org.my/?p=3316, dicapai pada 2 September 2017.

Harga Emas Trading, "Harga Emas Hari Ini”, laman sesawang Harga Emas Trading $S d n$ Bhd, http://www.hargaemas.com.my/, dicapai pada 10 Januari 2017.

Haslifah Hashim \& David Service (2013). "Modelling the Life Insurance Needs Using the Human Life Value Revision Method," Journal of Physics: Conference Series, 1-10.

Jawatankuasa Fatwa Kebangsaan (2003). "Muzakarah Jawatankuasa Fatwa Kebangsaan Bagi Hal Ehwal Ugama Islam Malaysia Kali Ke57," $\quad$ http://www.islam.gov.my/images/ePenerbitan/KOMPILASI MUZAKARAH_MKI_2016.pdf, dicapai pada 20 November 2017.

Khan, A. (n.d.). "Human Ignorance (Jahiliyyah): Past \& Present", The Dialogue, vol. 8, no. 4.

Kirazli, S. B. T.-I. S. (2011). "Conflict and Conflict Resolution in the preIslamic Arab Society," Journal of Islamic Studies, vol. 50, no. 1.

Mohd. Shukri Hanafi. (2013). "From Jahiliyyah to Islamic Worldview: In A Search of An Islamic Educational Philosophy." International Journal of Humanities and Social Science, vol. 3, no. 2.

Muhammad Hilmi Musa (2015). "Penggunaan Emas dan Perak dalam Menentukan Nilai Pampasan Diyat: Suatu Analisis ke Atas Nilaian Pertukaran Matawang Semasa," Jurnal Undang-undang dan Masyarakat. vol. 19, 17-28.

Muhammad Suhail Toqush (2009). Tarikh al- 'Arab Qabl al-Islām (Beirūt: Dār al-Nafa'is.

Paizah Ismail (2012). "Pelaksanaan Diyat dalam Kerangka Cabaran Fiqh Semasa," Jurnal Fiqh, vol. 9, no. 9, 1-20.

S. Santhana Dass (2000). Personal Injury Claims. Petaling Jaya: Alpha Sigma Sdn. Bhd.

Salleh Buang (1999). Undang-undang Kecuaian di Malaysia, terj. Asiah Mohd Yusof. Kuala Lumpur: Dewan Bahasa dan Pustaka.

Siti Zubaidah Ismail (1999). "Kemalangan Maut Jalan Raya Menurut Perspektif Undang-undang Malaysia dan Islam,” Jurnal Syariah, vol. 7, 91-106.

Yasin Ahmad Ibrahim (1990). Miqdār al-Diyah al-Nafs fi al-Syari'ah alIslāmiyyah wa Taqdiruha fi al-'Asr al-Hadir. Jurdan: Maktabah alBanin. 
Journal of Shariah Law Research (JSLR) 